\title{
Pelvic Floor 3D Ultrasound of Women with a TVT, TVT-O, or TVT-S for Stress Urinary Incontinence at the Three-year Follow-up
}

\section{Ultrassonografia tridimensional do assoalho pélvico após 3 anos de correção cirúrgica de incontinência urinária de esforço por sling retropúbico, transobturador, ou de incisão única}

\author{
Claudinei A. Rodrigues ${ }^{1}$ Ana Maria H. M. Bianchi-Ferraro ${ }^{1}$ Eliana Viana Monteiro Zucchi ${ }^{1}$ \\ Marair G. F. Sartori ${ }^{1}$ Manoel J. B. C. Girão ${ }^{1}$ Zsuzsanna I. K. Jarmy-Di Bella ${ }^{1}$
}

\footnotetext{
1 Sector of Urogynecology and Vaginal Surgery, Department of Gynecology, Universidade Federal de São Paulo, São Paulo, Brazil

Rev Bras Ginecol Obstet 2017;39:471-479.
}

\author{
Address for correspondence Claudinei Alves Rodrigues, MD, Setor de \\ Uroginecologia e Cirurgia Vaginal, Departmento de Ginecologia, \\ Universidade Federal de São Paulo, Alameda Joaquim Eugênio de \\ Lima, 913, Apt. 91, São Paulo, SP, 01403-001, Brazil \\ (e-mail: dinhodr@uol.com.br).
}

\begin{abstract}
Keywords

- urinary incontinence

- ultrasonography

- pelvic floor

Objective Using three-dimensional ultrasound (3D-US), we aimed to compare the tape position and the angle formed by the sling arms in different techniques of midurethral sling insertion for the surgical treatment of stress urinary incontinence, three years after surgery. In addition, we examined the correlations between the US findings and the clinical late postoperative results.

Methods A prospective cross-sectional cohort study of 170 patients who underwent a sling procedure between May 2009 and December 2011 was performed. The final sample, with US images of sufficient quality, included 26 retropubic slings (tension-free vaginal tape, TVT), 42 transobturator slings (tension-free vaginal tape-obturator, TVTO), and 37 single-incision slings (tension-free vaginal tape-Secur, TVT-S). The images (at rest, during the Valsalva maneuver, and during pelvic floor contraction) were analyzed offline by 2 different observers blinded against the surgical and urinary continence status. Group comparisons were performed using the Student $t$-test, the chi-squared and the Kruskal-Wallis tests, and analyses of variance with Tukey multiple comparisons. Results Differences among the groups were found in the mean angle of the tape arms $\left(\right.$ TVT $=119.94^{\circ}$, TVT$^{-O}=141.93^{\circ}$, TVT-S $\left.=121.06^{\circ} ; p<0.001\right)$ and in the distance between the bladder neck and the tape at rest (TVT $=1.65 \mathrm{~cm}$, TVT-O $=1.93 \mathrm{~cm}$, TVT$\mathrm{S}=1.95 \mathrm{~cm} ; p=0.010$ ). The global objective cure rate was of $87.8 \%$ (TVT $=88.5 \%$, TVT-O $=90.5 \%$, TVT-S $=83.8 \% ; p=0.701)$. The overall subjective cure rate was of
\end{abstract}

received

November 5, 2016

accepted

June 12, 2017

published online

August 28, 2017
DOI https://doi.org/

10.1055/s-0037-1606125. ISSN 0100-7203.
Copyright (e 2017 by Thieme Revinter

Publicações Ltda, Rio de Janeiro, Brazil
License terms

(c) $(1) \$$ 


\section{Resumo}

\section{Palavras-Chave \\ - incontinência urinária \\ - ultrassonografia \\ - assoalho pélvico}

83.8\% (TVT $=88.5 \%$, TVT-O $=88.5 \%$ and TVT-S $=78.4 \% ; p=0.514)$. The slings were located in the mid-urethra in $85.7 \%$ of the patients (TVT $=100 \%$, TVT-O $=73.8 \%$, TVT$\mathrm{S}=89.2 \% ; p=0.001$ ), with a more distal location associated with obesity (distal: $66.7 \%$ obese; mid-urethra: $34 \%$ obese; $p=0.003$ ). Urgency-related symptoms were observed in $23.8 \%$ of the patients (TVT $=30.8 \%$, TVT-O $=21.4 \%$, TVT-S $=21.6 \%$; $p=0.630$ ).

Conclusions The angle formed by the arms of the sling tape was more obtuse for the transobturator slings compared with the angles for the retropubic or single-incision slings. Retropubic slings were more frequently located in the mid-urethra compared with the other slings, regardless of obesity. However, the analyzed sonographic measures did not correlate with the urinary symptoms three years after the surgery.

Objetivo Comparar por meio de ultrassom tridimensional (US-3D) a posição e o ângulo entre os braços da faixa, em diferentes técnicas de inserção de sling de uretra média, para tratamento de incontinência urinária de esforço, 3 anos após a cirurgia, correlacionando os achados ultrassonográficos aos resultados clínicos pós-operatórios. Métodos Este é um estudo de coorte transversal prospectivo de 170 pacientes que se submeteram a um procedimento de sling entre maio de 2009 e dezembro de 2011. Foi possível avaliar as imagens de US em 105 pacientes: 26 com tension-free vaginal tape (TVT), 42 com tension-free vaginal tape-obturator (TVT-O) e 37 com tension-free vaginal tape-Secur (TVT-S). As imagens (em repouso, em manobra de Valsalva e em contração perineal) foram analisadas por dois observadores diferentes, que desconheciam o tipo de sling utilizado na cirurgia, assim como as queixas da paciente. A análise estatística foi realizada por meio dos testes $t$ de Student, qui-quadrado, Kruskal-Wallis, e análise de variância com comparações múltiplas de Tukey.

Resultados As médias dos ângulos entre os braços da faixa foram: TVT $=119,94^{\circ}$, TVT-O $=141,93^{\circ}$, TVT-S $=121,06^{\circ}(p<0,001)$. As médias das distâncias entre o colo vesical e a faixa, em repouso, foram: TVT $=1,65 \mathrm{~cm}$, TVT-O $=1,93 \mathrm{~cm}$, TVT$\mathrm{S}=1,95 \mathrm{~cm}(p=0,010)$. A taxa de cura objetiva dos slings foi de $87,8 \%$ (TVT $=88,5 \%$, TVT-O $=90,5 \%$ e TVT-S $=83,8 \% ; p=0,701)$. A taxa de cura subjetiva foi de $83,8 \%$ (TVT $=88,5 \%$, TVT-O $=88,5 \%$ e TVT-S $=78,4 \% ; p=0,514$ ). Os slings estavam na uretra média em $85,7 \%$ (TVT $=100 \%$, TVT-O $=73,8 \%$ e TVT-S $=89,2 \% ; p=0,001$ ) dos pacientes, e a localização mais distal foi associada a obesidade (distal: 66,7\% obesas; uretra média: $34 \%$ obesas; $p=0.003$ ). Os sintomas de urgência foram observados em $23,8 \%$ das pacientes (TVT $=30,8 \%$, TVT-O $=21,4 \%$, TVT-S $=21,6 \%$; $p=0,630$ ). Não houve diferenças significativas quando se comparam os achados ultrassonográficos e os grupos de pacientes com sintomas de urgência, cura subjetiva e objetiva.

Conclusão O ângulo formado pelos braços da faixa foi mais obtuso no TVT-O quando comparado com o TVT ou o TVT-S. Os TVTs foram localizados mais frequentemente na uretra média quando comparados com os outros dois grupos, mesmo em pacientes obesas. Entretanto, as medidas ultrassonográficas não tiveram correlação com os sintomas urinários três anos após a cirurgia.

\section{Introduction}

The current standard surgical treatment for stress urinary incontinence (SUI) involves tension-free mid-urethral sling (MUS) placement, either using the retropubic or transobturator approach, which has a reported success rate of up to
$80 \%$ at the long-term follow-up. ${ }^{1}$ More recently, single-incision slings were developed to minimize some of the risks related to MUSs, such as infection and chronic pain. However, this technique has not been well-accepted by the medical community due to the variability in insertion techniques and the diversity of materials used to ensure the fixation of the 
device, which has interfered with continence success. Thus, traditional MUSs are considered significantly superior to mini-slings in terms of cure outcomes. ${ }^{2-4}$

Although MUS operations are considered safe, complications such as urinary obstruction and postoperative urgency may occur. Imaging techniques can provide assistance in the diagnosis of these complications. ${ }^{5}$ Ultrasonography (US) is a widespread tool used to assess the anatomy and function of the pelvic floor structures. It is a non-invasive, reproducible, and technically simple method to visualize the lower urinary tract, particularly the urethra and the bladder, and an endovaginal or translabial convex probe can be used. ${ }^{6}$ Moreover, translabial three-dimensional ultrasound (3D-US) allows good visualization of the suburethral polypropylene sling tape in orthogonal planes (axial, coronal, mid-sagittal), and can be used to explain the pathogenesis of voiding dysfunction following synthetic sling procedures. ${ }^{7}$ Thus, US during the postoperative period has shown an increasing role in the monitoring of surgically treated patients, especially for complications such as urinary retention and urinary disorders. However, there are few studies that correlate the information obtained by 3D-US and the prognostic and predictive markers of SUI treatment with synthetic slings. ${ }^{7}$

Therefore, the present study utilized translabial 3D-US 3 years after surgeries for the cure of SUI to evaluate and compare the spatial position of the polypropylene sling tape for 3 different SUI correction techniques: MUS using the retropubic approach (tension-free vaginal tape, TVT), the transobturator approach (tension-free vaginal tape-obturator, TVT-O), and the single-incision sling (tension-free vaginal tape-Secur, TVT-S). In addition, the relationship between the 3D-US findings and the objective/subjective cure rates and urgency-related symptoms was examined. Our hypothesis was that the angle formed by the arms of the tape following TVT insertion is the most acute, causing more post-operative urgencies, whereas the angle following TVT-O insertion is more obtuse and, consequently, results in more failures of SUI correction. In addition, we expected the TVT-S, which is not currently on the market, to act similarly to the TVT. Moreover, we hypothesized that if the tape is located in the mid-urethra, the better the long-term clinical postoperative results.

\section{Methods}

\section{Subjects}

A prospective cross-sectional cohort study of patients who underwent a sling procedure at the Urogynecology and Vaginal Surgery Sector of our institution between May 2009 and December 2011 was performed. All patients who underwent the surgery during the study period were invited (via phone) to participate. The inclusion criteria were: women over 18 years-old who had undergone SUI treatment with MUS (using the retropubic or transobturator routes) or a single-incision sling without any concomitant pelvic floor surgical procedures. In addition, the patient should have had a preoperative diagnosis of SUI without detrusor overactivity. The exclusion criteria were as follows: incomplete medical records relating to surgical hospitalization, urinary incontinence previously treated by surgery with a polypropylene implant, or undergoing new treatments for urinary incontinence during the follow-up period. Total of 170 patients were eligible to participate in the study (48 with TVTs, 56 with TVT-Os, and 66 with TVT-Ss). Among these, 115 accepted the invitation, being thus selected and placed in each group according to the surgery performed (TVT: 26; TVT-0: 46; TVT-S: 43). However, 10 evaluated patients were excluded from the analysis ( 2 women presented with 2 synthetic slings at US, and 3D-US images did not have perfect technical quality in 8 cases), resulting in a final sample of 105 patients (TVT: 26; TVT-O: 42; TVT-S: 37 ). The patient selection process is depicted in - Fig. 1 .

An urodynamic study was performed before the surgery, and the results of the Valsalva leak point pressure (VLPP, mean and standard deviation) were $67.64 \pm 19.20 \mathrm{cmH} 2 \mathrm{O}$, $87.57 \pm 32.14 \mathrm{cmH} 2 \mathrm{O}$ and $85.14 \pm 27.05 \mathrm{cmH} 2 \mathrm{O}$, for the TVT, TVT-O and TVT-S groups respectively.

A sample power calculation was performed using the results of a previous publication, ${ }^{7}$ which involved the evaluation of the angles formed by the arms of the polypropylene tape in sonographic images at rest and during the Valsalva maneuver. At rest, the mean values considered in the sample calculation were $116^{\circ}$ and $137^{\circ}$, respectively for the TVT and TVT-O groups, and the overall standard deviation considered was 7. During the Valsalva maneuver, the mean values were $130^{\circ}$ (TVT) and $140^{\circ}$ (TVT-O), with a standard deviation of 10. Considering the power of the sample of $80 \%, 4$ patients per group at rest and 17 patients per group during the Valsalva maneuver would be necessary. A $p$-value $<0.05$ was considered statistically significant.

The study was approved by the National Ethics in Research Committee, and the trial was appropriately registered on www.clinicaltrials.gov (NCT 02406638). All participants provided written informed consent, and the research was performed according to the Declaration of Helsinki, as revised in 2008 .

\section{Procedures}

The TVT surgery was performed according to the classical technique, ${ }^{8}$ using Gynecare TVT (Ethicon Inc., Somerville, New Jersey, US). The TVT-O procedure was performed according to the inside-out technique proposed by de Leval, ${ }^{9}$ using the Gynecare TVT Obturator System (Ethicon Inc., Somerville, New Jersey, US). The single-incision sling (TVTSecur, Gynecare TVT Secur System, Ethicon Inc., Somerville, New Jersey, US) was inserted using the "U" insertion technique. ${ }^{10}$ The manufacturer discontinued the commercialization of the TVT-S in 2012. ${ }^{11}$

Three-dimensional US imaging and a clinical evaluation were performed between April 2013 and June 2014. The physical examination involved stress tests, including the 250 -ml bladder volume and the 20 -minute pad tests. ${ }^{12}$ In addition, the quality of life was assessed using the King Health Questionnaire (KHQ), which had been previously validated for the Portuguese language. ${ }^{13}$ Objective cure was defined as the absence of urinary leakage during the stress tests. Subjective 


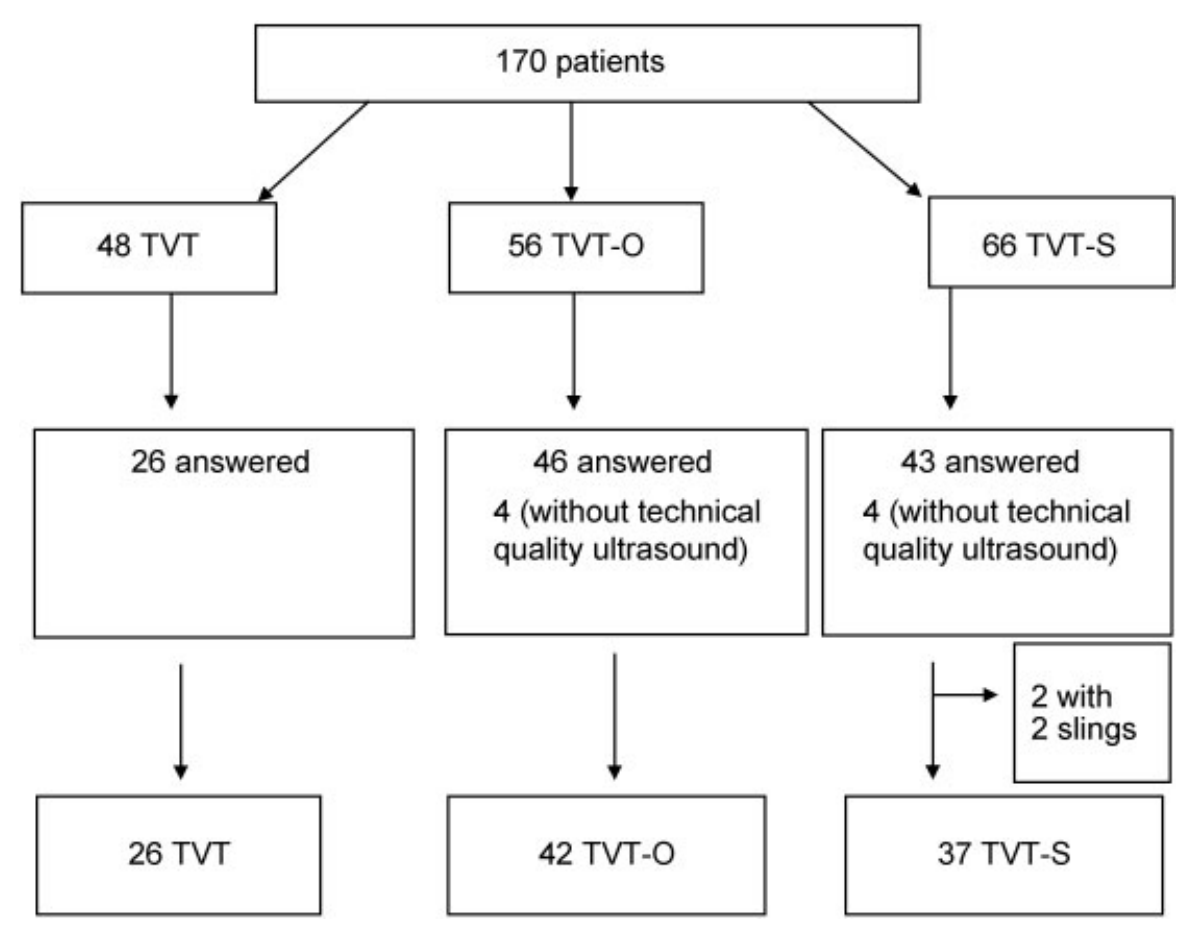

Fig. 1 Patient selection flowchart: the patient selection process is depicted. Abbreviations: TVT, tension-free vaginal tape (retropubic sling); TVT-O, tension-free vaginal tape-obturator (transobturator sling); TVT-S, tension-free vaginal tape-Secur (single-incision sling).

cure was defined as the absence of self-reported urinary leakage as indicated by a KHQ symptoms scale score of 0 . The presence of urgency-related symptoms was also evaluated using the KHQ symptoms scale.

Three-dimensional US was performed after voiding, with the patient in the lithotomy position, with the hips flexed and abducted; it was performed at rest, during the Valsalva maneuver, and during perineal contraction. The 3D-US equipment (Voluson 730 Expert, General Electric [GE] Healthcare, Zipf, Austria) included a convex volumetric transducer covered by a plastic transducer (4-8 Mhz) with an acquisition angle of $85^{\circ}$.

The obtained images of the pelvic floor were later evaluated using the 4D View (version 14, ext 0; GE Kretz Ultrasound, GE Healthcare, Zipf, Austria) software on a computer with the Windows system. For the analysis of the images, the sagittal plane (two-dimensional [2D] image) was selected with the sight line through the pubis, the urethra, and the polypropylene sling tape. ${ }^{14}$ The assessors of the ultrasound data were blinded against all clinical data. The measurements of the urethral length (UL) and the distance between the bladder neck and the central point of the tape (BT) were performed using a 2D-US image in the mid-sagittal plane ( $\boldsymbol{- F i g . ~ 2}$ ). The tape displacement in relation to the UL was measured as the difference between the ratio of the BT and UL at rest and during the Valsalva maneuver or pelvic floor contraction. For an evaluation of the relative position of the tape, we divided the BT by the UL, and the resulting number was used to classify the position of the tape within the urethra. The tape was considered to be: in the proximal-third (closest to the bladder neck) if the result was between 0 and 0.33 ; in the middle-third if the result was between 0.34 and 0.66 ; and in the distal-third (closest to the external urethral ostium) if the result was between 0.67 and 1.0.
The OmniView volume contrast imaging (VCI) mode (GE Healthcare, Zipf, Austria) was used during the image analysis, sliding digitally with a straight line passing through the lower edge of the pubic symphysis, the urethra, and the lower tape. In order to improve visibility, VCI was selected, with a thickness of $3.0 \mathrm{~mm}$, which allowed the visualization of the pubis, the urethra, the vagina, the tape, and the rectum (-Fig. 2). ${ }^{15}$ The OmniView-VCI mode was used to evaluate the angle formed by the tape arms $\left(\mathrm{A}^{\circ}\right)$, as well as the distance between the posterior inferior symphysis margin and the echogenic center of the urethra (PU), and the distance between the echogenic center of the urethra and the tape (UT) (-Fig. 2). The mobility of the urethra during movement was calculated as the difference between the PU at rest and the PU during the Valsalva maneuver or pelvic floor contraction.

Statistical analyses were performed using the Minitab software (Minitab, Inc., State College, PA, US), version 16. The Mann-Whitney test was used for the continuous nonparametric variables, and the Student $t$-test was used for the continuous parametric variables. The Chi-squared, Fisher, Kruskal-Wallis, and Pearson correlation tests were used for the nominal variables. Analyses of variance (ANOVAs) for continuous variables were performed using the Tukey multiple comparison procedure. A $p$-value $<0.05$ was considered statistically significant. ${ }^{16,17}$

\section{Results}

The three surgical groups (26 TVT, 42 TVT-O, and 37 Minisling TVT-S) were similar in terms of age, body mass index (BMI), the number of vaginal or caesarean deliveries, and hormonal status, as shown in - Table 1. At the time of the 

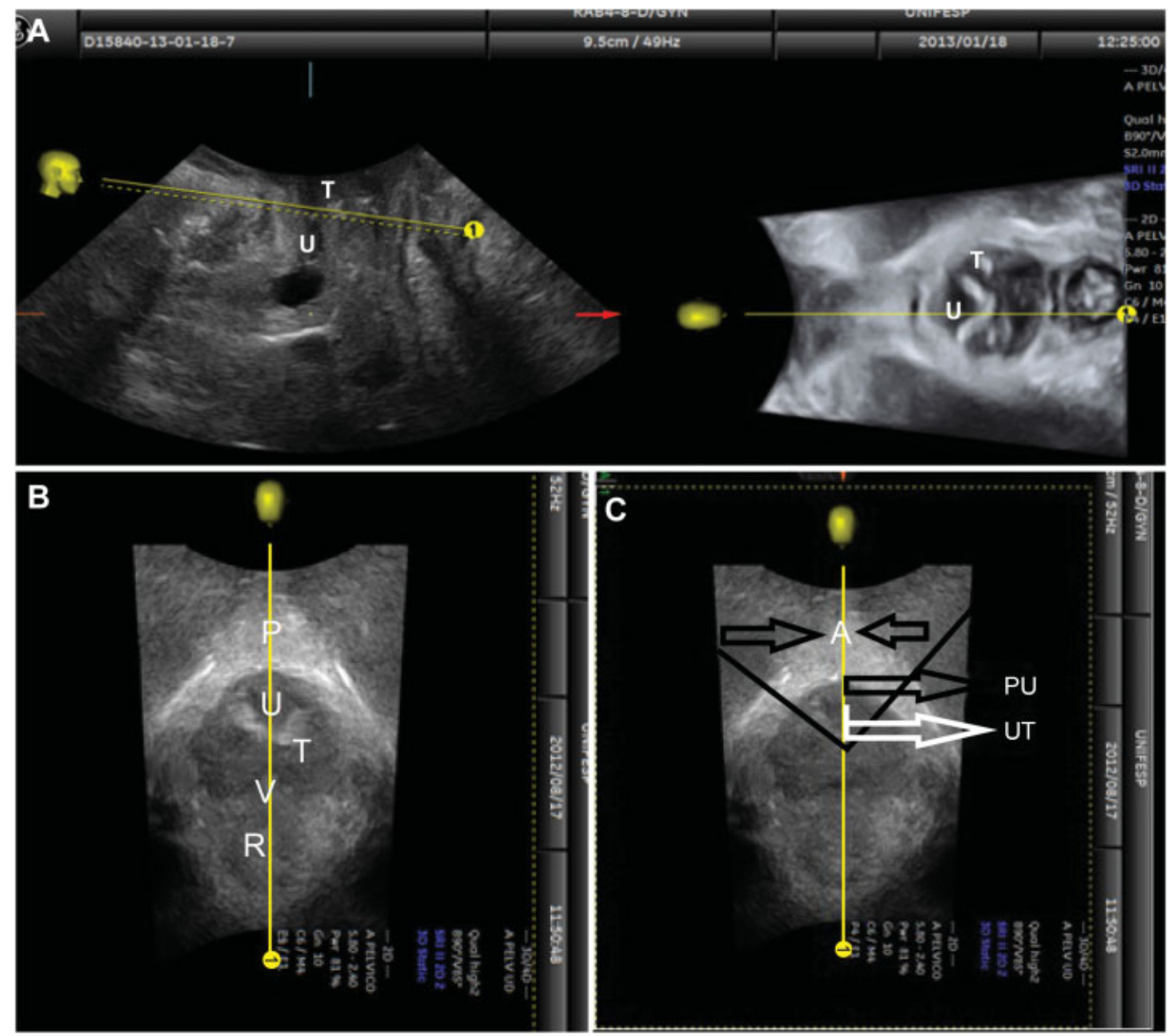

Fig. 2 Example images: (A) a 2D-US mid-sagittal plane (left) and 3D OmniView axial image (right) image of the pelvic floor are shown. Note the sling position (white hyperechoic structure - T) and urethra (hypoechoic structure - U). Two images below- OmniView mode: The axial plane on the OmniView mode with pelvic floor organs, at the left (B), and measurements, at the right (C), is shown. Abbreviations: $A^{\circ}$, angle between the two arms of the sling; $P$, symphysis pubis; PU, distance between the symphysis pubis and the urethra; R, rectum; T, polypropylene tape (sling); $U$, urethra; UT, distance between the tape and the urethra; $V$, vagina.

evaluation, the postoperative time ranged between 36 and 40 months.

The 2D-US measurements obtained in the mid-sagittal plane are presented in $\mathbf{- T a b l e ~} \mathbf{2}$. The UL at rest, during the
Valsalva maneuver, and during pelvic floor contraction did not significantly differ among the three groups. In contrast, there were differences among the groups regarding the BT. Specifically for the TVT group, the tape was significantly

Table 1 Patient characteristics

\begin{tabular}{|l|l|l|l|l|}
\hline & $\begin{array}{l}\text { TVT }(\boldsymbol{n}=26) \\
\text { Mean (SD) }\end{array}$ & $\begin{array}{l}\text { TVT-O }(\boldsymbol{n}=42) \\
\text { Mean (SD) }\end{array}$ & $\begin{array}{l}\text { TVT-S }(\boldsymbol{n}=37) \\
\text { Mean (SD) }\end{array}$ & $p$ \\
\hline Age (Years) & $58.35(9.79)$ & $55.00(10.77)$ & $54.51(13.2)$ & $0.384^{\mathrm{a}}$ \\
\hline BMI $\left(\mathrm{Kg} / \mathrm{m}^{2}\right)$ & $27.87(3.66)$ & $30.41(5.16)$ & $29.50(5.35)$ & $0.121^{\mathrm{a}}$ \\
\hline Caesarean delivery & $0.42(0.86)$ & $0.52(0.89)$ & $0.62(0.83)$ & $0.372^{\mathrm{b}}$ \\
\hline Vaginal delivery & $1.89(1.11)$ & $2.71(2.11)$ & $3.05(2.73)$ & $0.130^{\mathrm{b}}$ \\
\hline Menopause (\%) & $22(84.60 \%)$ & $26(61.90 \%)$ & $24(64.86 \%)$ & $0.122^{\mathrm{c}}$ \\
\hline
\end{tabular}

Abbreviations: BMI, body mass index; SD, standard deviation; TVT, tension-free vaginal tape (retropubic sling); TVT-O, tension-free vaginal tape-obturator (transobturator sling); TVT-S, tension-free vaginal tape-Secur (single-incision sling).

Notes: ${ }^{a}$ ANOVA; ${ }^{b}$ Kruskal-Wallis test; ${ }^{c}$ Chi-squared test. The values are represented as mean and SD (range) and $\mathrm{n}(\%)$, and are attributed to patients who underwent surgical treatment for stress urinary incontinence using a retropubic sling (TVT), a transobturator sling (TVT-O), or a single-incision sling (TVT-S). 
Table 2 Midsagittal sonographic and OmniView-VCI mode measurements

\begin{tabular}{|c|c|c|c|c|}
\hline & $\begin{array}{l}\text { TVT }(n=26) \\
\text { Mean (SD) }\end{array}$ & $\begin{array}{l}\text { TVT-O }(n=42) \\
\text { Mean }(\mathrm{SD})\end{array}$ & $\begin{array}{l}\text { TVT-S }(n=37) \\
\text { Mean (SD) }\end{array}$ & $p$ \\
\hline Urethral length: rest $(\mathrm{cm})$ & $3.34(0.37)$ & $3.24(0.40)$ & $3.36(0.45)$ & $0.38^{*}$ \\
\hline Urethral length: Valsalva $(\mathrm{cm})$ & $3.26(0.30)$ & $3.18(0.40)$ & $3.25(0.42)$ & $0.63^{*}$ \\
\hline Urethral length: contraction (cm) & $3.56(0.42)$ & $3.34(0.39)$ & $3.53(0.49)$ & $0.07^{*}$ \\
\hline BT: rest $(\mathrm{cm})$ & $1.65(0.26)$ & $1.93(0.38)$ & $1.95(0.51)$ & $0.01^{*}$ \\
\hline BT: Valsalva $(\mathrm{cm})$ & $1.67(0.24)$ & $1.85(0.37)$ & $1.89(0.50)$ & $0.08^{*}$ \\
\hline BT: contraction $(\mathrm{cm})$ & $1.81(0.38)$ & $2.03(0.39)$ & $2.03(0.57)$ & $0.11^{*}$ \\
\hline Mid-urethra tape n (\%): rest & $26(100 \%)$ & $31(73.8 \%)$ & $33(89.2 \%)$ & $0.008^{*}$ \\
\hline Mid-urethra tape n (\%):Valsalva & $26(100 \%)$ & $33(78.6 \%)$ & $29(78.4 \%)$ & $0.036^{*}$ \\
\hline Mid-urethra tape n (\%): contraction & $26(100 \%)$ & $31(73.8 \%)$ & $32(86.5 \%)$ & $0.013^{*}$ \\
\hline$A^{\circ}$ : rest & $119.94(19.66)$ & $141.93(14.25)$ & $121.06(14.24)$ & $<0.001$ \\
\hline $\mathrm{A}^{\circ}$ : Valsalva & $130.79(21.78)$ & $14 ., 48(13.23)$ & $124.40(24.79)$ & $<0.001$ \\
\hline$A^{\circ}$ : contraction & $120.94(16.63)$ & $144.77(16.51)$ & $126.53(18.20)$ & $<0.001$ \\
\hline PU: rest $(\mathrm{cm})$ & $1.68(0.28)$ & $1.53(., 25)$ & $1.64(0.29)$ & $0.08^{*}$ \\
\hline PU: Valsalva $(\mathrm{cm})$ & $1.72(0.29)$ & $1.59(0.28)$ & $1.64(0.14)$ & $0.19^{*}$ \\
\hline PU: contraction $(\mathrm{cm})$ & $1.65(0.27)$ & $1.49(0.29)$ & $1.66(0.31)$ & $0.02^{*}$ \\
\hline UT: rest $(\mathrm{cm})$ & $0.67(0.14)$ & $0.73(0.15)$ & $0.71(0.11)$ & $0.21^{*}$ \\
\hline UT: Valsalva $(\mathrm{cm})$ & $0.65(0.13)$ & $0.68(0.14)$ & $0.75(0.14)$ & $0.01^{*}$ \\
\hline UT: contraction $(\mathrm{cm})$ & $0.60(0.01)$ & $0.65(0.15)$ & $0.66(0.10)$ & $0.16^{*}$ \\
\hline
\end{tabular}

Abbreviations: $\mathrm{A}^{\circ}$, angle of the two arms of the sling; $\mathrm{BT}$, distance between the bladder neck and the tape; $\mathrm{PU}$, distance between the symphysis pubis and the urethra; SD, standard deviation; TVT, tension-free vaginal tape (retropubic sling); TVT-O, tension-free vaginal tape-obturator (transobturator sling); TVT-S, tension-free vaginal tape-secure (single-incision sling); UT, distance between the tape and the urethra.

Notes: ANOVA, Tukey multiple comparisons. The midsagittal sonographic measurements and OmniView- $\mathrm{VCl}$ mode measurements of patients who underwent surgical treatment for stress urinary incontinence using a retropubic sling (TVT), a transobturator sling (TVT-O), or a single-incision sling (TVT-S) are provided.

closer to the bladder neck compared with the other groups during rest $(p=0.001)$, but not during the Valsalva maneuver $(p=0.08)$ or pelvic floor contraction $(p=0.11)$. There was no significant difference in the displacement of the tape among the three groups.

The location of the sling relative to the urethra was different among the groups at rest and during movement (rest: $p<0.001$; Valsalva: $p=0.008$; pelvic floor contraction: $p<0.001$ ). Specifically in the TVT group, all tapes $(100 \%)$ were located in the mid-urethra during rest and during movement (Valsalva maneuver and pelvic floor contraction). However, for the TVT-O group, only 31 out of 42 tapes $(73.8 \%)$ were located in the mid-urethra at rest, and for the TVT-S group, 33 out of 37 tapes (89.2\%) were located in the mid-urethra at rest. Furthermore, during the Valsalva maneuver, $78.6 \%$ of tapes in the TVT-O group and $78.4 \%$ in the TVT-S group were located in the mid-urethra. During pelvic floor contraction, only $73.8 \%$ of the tapes in the TVT-0 group and $86.5 \%$ in the TVT-S group were located in the mid-urethra.

Of the 15 patients with the tape located in the distal urethra, $66.7 \%$ had a BMI $>30 \mathrm{~kg} / \mathrm{m}^{2}$ (obese status). In contrast, of the 90 patients with the tape located in the mid-urethra, only $34 \%$ were obese as assessed by BMI (mid- urethra versus distal urethra: $p=0.003$ ). The total sample had 40/105 (38\%) obese patients.

The measurements taken using the OmniView-VCI mode are shown in - Table $\mathbf{2}$. The angle formed by the arms of the sling was not significantly different between the TVT and TVT-S groups, but was more obtuse in the TVT-O group compared with the other groups during rest $(p<0.001)$, during the Valsalva maneuver $(p<0.001)$, and during pelvic floor contraction $(p<0.001)$. There were no significant group differences regarding the PU, at rest or during movement. While the UT at rest and during pelvic floor contraction did not show differences among the groups, during the Valsalva maneuver, the UT significantly differed among the groups $(p=0.01)$, with a smaller UT in the TVT group compared with the TVT-S group. No significant differences among the groups regarding urethral mobility during the Valsalva maneuver and during pelvic floor contraction were found ( $p=0.78$ and $p=0.51$ respectively).

Information on subjective and objective cure is presented in -Table 3. A subjective cure was achieved by 88 of the 105 patients $(83.8 \%)$, with no difference among the groups $(p=0.701)$. An objective cure was verified in $92 / 105$ (87.8\%) patients, with no difference among the groups $(p=0.514)$. The presence of urgency-related symptoms 
Pelvic Floor 3D-US of Women with TVT, TVT-O, or TVT-S for Urinary Incontinence at 3-year Follow-up Rodrigues et al. 477

Table 3 Urinary symptoms

\begin{tabular}{|l|l|l|l|l|l|}
\hline & TVT & TVT-O & TVT-S & TOTAL & $p$ \\
\hline Subjective cure & $23(88.5 \%)$ & $36(85.7 \%)$ & $29(78.4 \%)$ & $88(83.8 \%)$ & $0.514^{\mathrm{a}}$ \\
\hline Objective cure & $23(88.5 \%)$ & $38(90.5 \%)$ & $31(83.8 \%)$ & $92(87.8 \%)$ & $0.701^{\mathrm{b}}$ \\
\hline Urgency symptoms & $8(30.8 \%)$ & $9(21.4 \%)$ & $8(21.6 \%)$ & $25(23.8 \%)$ & $0.630^{\mathrm{a}}$ \\
\hline TOTAL & $26(100 \%)$ & $42(100 \%)$ & $37(100 \%)$ & $105(100 \%)$ & \\
\hline
\end{tabular}

Abbreviations: TVT, tension-free vaginal tape (retropubic sling); TVT-O, tension-free vaginal tape-obturator (transobturator sling); TVT-S, tension-free vaginal tape-secure (single-incision sling).

Notes: ${ }^{a}$ Chi-squared test; ${ }^{b}$ Fisher exact test. The subjective and objective cure rates and the rate of urgency-related symptoms for patients who underwent surgical treatment for stress urinary incontinence using a retropubic sling (TVT), a transobturator sling (TVT-O), or a single-incision sling (TVT-S) are provided.

Table 4 Associations between ultrasound measurements and urinary symptoms

\begin{tabular}{|c|c|c|c|c|c|c|c|c|c|}
\hline & \multicolumn{3}{|c|}{ Subjective cure } & \multicolumn{3}{|c|}{ Objective cure } & \multicolumn{3}{|c|}{ Urgency symptoms } \\
\hline & YES & NO & \multirow[t]{4}{*}{$p$} & YES & NO & \multirow[t]{4}{*}{$p$} & YES & NO & \multirow[t]{4}{*}{$p$} \\
\hline & $(n=88)$ & $(n=17)$ & & $(n=92)$ & $(n=13)$ & & $(n=25)$ & $(n=25)$ & \\
\hline & M & M & & M & M & & M & M & \\
\hline & (SD) & (SD) & & (SD) & (SD) & & (SD) & (SD) & \\
\hline \multirow[t]{2}{*}{ BT: rest $(\mathrm{cm})$} & 1.87 & 1.86 & \multirow[t]{2}{*}{$0.96^{*}$} & 1.85 & 1.98 & \multirow[t]{2}{*}{$0.50^{*}$} & 1.76 & 1.76 & \multirow[t]{2}{*}{$0.25^{*}$} \\
\hline & $(0.38)$ & $(0.62)$ & & $(0.38)$ & $(0.66)$ & & $(0.52)$ & $(0.52)$ & \\
\hline \multirow[t]{2}{*}{ BT: Valsalva (cm) } & 1.8 & 1.95 & \multirow[t]{2}{*}{$0.29^{*}$} & 1.79 & 2.02 & \multirow[t]{2}{*}{$0.24^{*}$} & 1.85 & 1.85 & \multirow[t]{2}{*}{$0.74^{*}$} \\
\hline & $(0.35)$ & $(0.59)$ & & $(0.35)$ & $(0.66)$ & & $(0.48)$ & $(0.48)$ & \\
\hline \multirow[t]{2}{*}{ BT: contraction (cm) } & 1.96 & 2.01 & $0.80^{*}$ & 1.95 & 2.12 & $0.37^{*}$ & 1.93 & 1.93 & $0.60^{*}$ \\
\hline & $(0.44)$ & $(0.60)$ & & $(0.43)$ & $(0.64)$ & & $(0.50)$ & $(0.50)$ & \\
\hline \multirow[t]{2}{*}{ Ratio BT/UL: rest } & 0.57 & 0.55 & \multirow[t]{2}{*}{$0.62^{*}$} & 0.56 & 0.57 & \multirow[t]{2}{*}{$0.71^{*}$} & 0.53 & 0.53 & \multirow[t]{2}{*}{$0.09^{*}$} \\
\hline & $(0.09)$ & $(0.12)$ & & $(0.09)$ & $(0.12)$ & & $(0.11)$ & $(0.11)$ & \\
\hline \multirow[t]{2}{*}{ Ratio BT/UL: Valsalva } & 0.56 & 0.57 & \multirow[t]{2}{*}{$0.68^{*}$} & 0.56 & 0.58 & \multirow[t]{2}{*}{$0.61^{*}$} & 0.56 & 0.56 & \multirow[t]{2}{*}{$0.64^{*}$} \\
\hline & $(0.09)$ & $(0.13)$ & & $(0.09)$ & $(0.14)$ & & $(0.02)$ & $(0.02)$ & \\
\hline \multirow[t]{2}{*}{ Ratio BT/LU: contraction } & 0.57 & 0.57 & \multirow[t]{2}{*}{$0.10^{*}$} & 0.57 & 0.58 & \multirow[t]{2}{*}{$0.62^{*}$} & 0.56 & 0.56 & \multirow[t]{2}{*}{$0.56^{*}$} \\
\hline & $(0.09)$ & $(0.09)$ & & $(0.10)$ & $(0.10)$ & & $(0.10)$ & $(0.10)$ & \\
\hline \multirow[t]{2}{*}{$A\left({ }^{\circ}\right)$ : rest } & $129.2^{\circ}$ & $127.9^{\circ}$ & \multirow[t]{2}{*}{$0.81^{*}$} & $128.3^{\circ}$ & $133.9^{\circ}$ & \multirow[t]{2}{*}{$0.35^{*}$} & $128.5^{\circ}$ & $128.5^{\circ}$ & \multirow[t]{2}{*}{$0.89^{*}$} \\
\hline & $(18.5)$ & $(21.3)$ & & $(18.8)$ & $(19.6)$ & & $(21.5)$ & $(21.5)$ & \\
\hline A $\left({ }^{\circ}\right)$ : Valsalva & $136.6^{\circ}$ & $133.2^{\circ}$ & $0.58^{*}$ & $135.6^{\circ}$ & $139.3^{\circ}$ & $0.94^{*}$ & $136.3^{\circ}$ & $136.3^{\circ}$ & $0.99^{*}$ \\
\hline & $(23.0)$ & $(22.6)$ & & $(23.0)$ & $(22.2)$ & & $(21.4)$ & $(21.4)$ & \\
\hline A $\left({ }^{\circ}\right)$ : contraction & $132.4^{\circ}$ & $132.5^{\circ}$ & $0.99^{*}$ & $131.4^{\circ}$ & $139.9^{\circ}$ & $0.26^{*}$ & $133.3^{\circ}$ & $133.3^{\circ}$ & $0.82^{*}$ \\
\hline & (18.9) & $(25.2)$ & & (19.0) & $(24.8)$ & & $(23.2)$ & $(23.2)$ & \\
\hline Urethral mobility: & -0.03 & -0.06 & $0.73^{*}$ & -0.04 & -0.05 & $0.87^{*}$ & -0.08 & -0.08 & $0.31^{*}$ \\
\hline rest-Valsalva (cm) & $(0.24)$ & $(0.31)$ & & $(0.25)$ & $(0.31)$ & & $(0.23)$ & $(0.23)$ & \\
\hline Urethral mobility: & 0.03 & 0.04 & $0.36^{*}$ & 0.03 & 0.03 & $0.52^{*}$ & 0.011 & 0.011 & $0.86^{*}$ \\
\hline rest & $(0.21)$ & $(0.31)$ & & 0.21 & $(0.32)$ & & $(0.27)$ & $(0.27)$ & \\
\hline
\end{tabular}

Abbreviations: A, Angle of the two arms of the sling; BT, distance between the bladder neck and tape; M, mean; SD, standard deviation; UL, urethral length. Notes: Student $t$-test. The results of the analyses examining the potential associations between sonographic measurements and urinary symptoms are provided for patients who underwent surgical treatment for stress urinary incontinence using a retropubic sling (TVT), a transobturator sling (TVT-O) or a single-incision sling (TVT-S). 
Table 5 Quality of life assessments (King Health Questionnaire)

\begin{tabular}{|l|l|l|l|l|}
\hline & $\begin{array}{l}\text { TVT-R } \\
\text { Mean }\end{array}$ & $\begin{array}{l}\text { TVT-O } \\
\text { Mean }\end{array}$ & $\begin{array}{l}\text { TVT-S } \\
\text { Mean }\end{array}$ & $p$ \\
\hline General health & 29.81 & 24.40 & 25.68 & $0.28^{*}$ \\
\hline Incontinence impact & 12.82 & 13.49 & 13.51 & $0.92^{*}$ \\
\hline $\begin{array}{l}\text { Limitations to daily } \\
\text { activities }\end{array}$ & 10.26 & 8.33 & 13.06 & $0.67^{*}$ \\
\hline $\begin{array}{l}\text { Limitations to physical } \\
\text { activities }\end{array}$ & 11.54 & 7.14 & 11.56 & $0.56^{*}$ \\
\hline Social limitations & 10.26 & 3.70 & 6.01 & $0.62^{*}$ \\
\hline $\begin{array}{l}\text { Impact on personal } \\
\text { relationships }\end{array}$ & 3.92 & 3.09 & 5.36 & $0.86^{*}$ \\
\hline Impact on emotions & 6.41 & 9.52 & 9.31 & $0.73^{*}$ \\
\hline $\begin{array}{l}\text { Impact on sleep } \\
\text { arrangement }\end{array}$ & 8.97 & 6.75 & 5.41 & $0.58^{*}$ \\
\hline Severity measure & 13.14 & 10.52 & 9.01 & $0.69^{*}$ \\
\hline
\end{tabular}

Abbreviations: TVT, tension-free vaginal tape (retropubic sling); TVT-O, tension-free vaginal tape-obturator (transobturator sling); TVT-S, tension-free vaginal tape-secur (single-incision sling).

Notes: Kruskal Wallis test. Quality of life data as assessed using the King Health Questionnaire are provided for patients who underwent surgical treatment for stress urinary incontinence using a retropubic sling (TVT), a transobturator sling (TVT-O) or a single-incision sling (TVT-S).

was observed in 25/105 (23.8\%) patients, with no difference among the groups $(p=0.630)$.

Correlations between the tape's spatial position and the clinical results are shown in - Table 4. No significant relationships were found, except for the displacement of the tape in relation to the UL between rest and contraction, which was slightly greater in the direction of the bladder neck in patients with urgency-related symptoms compared with those without symptoms $(p=0.03)$. No significant differences among the groups were found for the domains of the KHQ (-Table 5).

\section{Discussion}

Three-dimensional US imaging of the pelvic floor is a noninvasive and reproducible technique for the evaluation of postoperative MUS, and it enables a dynamic assessment of the polypropylene sling tape, with good visibility during rest, pelvic floor contraction, and the Valsalva maneuver. ${ }^{7}$

The BT found in the present study is consistent with previously published data. ${ }^{18,19}$ In addition, for the majority of the patients (85.7\%), the sling was located in the midurethra, and all other patients had slings located in the distal urethra (14.3\%). These results are also similar to those obtained by others researchers. ${ }^{19-21}$ We observed that $66.7 \%$ of the patients with the tape located in the distal urethra had a BMI $>30 \mathrm{~kg} / \mathrm{m}^{2}$ (obese status), while among those with the tape located in the mid-urethra, only $34 \%$ were obese. Thus, obesity appears to be a factor favoring a more distal position of the sling. However, the tape remained located in the mid-urethra in all individuals in the TVT group, thus showing a better location in obese patients as well, three years after the surgery.

The angle formed by the tape arms was less obtuse in the TVT and TVT-S groups compared with the TVT-O group (at rest, during the Valsalva maneuver, and during pelvic floor contraction), with no differences between the TVT and TVT-S groups. This finding was as we expected, and it may be explained by features of the sling insertion technique. ${ }^{7,22}$ For the TVT-O, the insertion was in a "hammock" position, while for the TVT and TVT-S, the insertion was in a "U" position. The "U" position was considered the best way to insert the TVT-S before its commercialization was discontinued.

It is interesting to note that no differences among the surgical techniques were identified with regard to tape displacement or urethra mobility, in rest or during movement, which is as expected, given that the three surgical procedures are meant to stabilize urethral mobility.

The distance between the urethra and the tape was smaller in the TVT group compared with the TVT-S group during the Valsalva maneuver only. This finding could suggest a higher frequency of postoperative urgency-related symptoms with the TVT. However, similarly to previous studies, we did not observe any differences between TVT and TVT-O groups in terms of this sonographic measure. ${ }^{22}$

Even though no associations between the position of the MUS tape and the clinical results were found, it was noted that, in patients with urgency-related symptoms, the tape tended to move more toward the bladder neck during the Valsalva maneuver. On the other hand, during pelvic floor contraction, there was a greater displacement of the tape toward the bladder neck in patients who reported urgencyrelated symptoms compared with patients without these symptoms. This may be a mechanism that explains the onset of de novo urgency in the postoperative period.

A lack of correlation between the tape position and the clinical outcomes has been previously reported ${ }^{6,20,23}$ and was confirmed in the present study, suggesting that factors other than tape position could influence the results of the insertion of the MUS. ${ }^{23,24}$ Although some sonographic measurements reached statistical significance in the group comparisons, the differences are on the order of millimeters, and are not clinically significant.

The limitations of the present study include the crosssectional design, with only a midterm postoperative followup. Therefore, we were not able to compare the preoperative and postoperative results or evaluate the earlier failures requiring surgical re-intervention, which could be related to tape position, as suggested by other studies. ${ }^{24,25}$ However, our study sample does reproduce the results from the literature regarding the objective and subjective cure rates and the frequency of urinary urgency symptoms, according to the different surgical techniques. ${ }^{1,2}$

\section{Conclusion}

In conclusion, we observed differences in the synthetic sling position three years after surgery when comparing different routes of insertion. In the retropubic approach, the tape was 
more frequently located in the mid-urethra compared with the transobturator route and the single-incision sling. Regarding the angle of the sling arms, it was more obtuse with the transobturator route, and it was, in a similar manner, more acute with the retropubic route and the single-incision sling. Although a relationship between the position of the MUS tape and the subjective/objective cure three years after surgery was not demonstrated, there was a correlation between the movement of the tape during pelvic floor contraction and the presence of symptoms of urgency.

Funding

This work was supported by Universidade Federal de São Paulo.

Conflicts of Interest

Authors have no conflicts of interest to disclose.

\section{Registration}

Clinical Trials.gov Protocol Registration System, http://www. clinicaltrials.gov, NCT 02406638, Pelvic Floor 3D USG Three Years After Mid-urethral Slings (TVT-R, TVT-O, TVT-S).

\section{References}

1 Ogah J, Cody DJ, Rogerson L. Minimally invasive synthetic suburethral sling operations for stress urinary incontinence in women: a short version Cochrane review. Neurourol Urodyn 2011;30(03):284-291

2 Mostafa A, Lim CP, Hopper L, Madhuvrata P, Abdel-Fattah M. Single-incision mini-slings versus standard midurethral slings in surgical management of female stress urinary incontinence: an updated systematic review and meta-analysis of effectiveness and complications. Eur Urol 2014;65(02):402-427

3 Bianchi-Ferraro AM, Jarmy-DiBella ZI, de Aquino Castro R, Bortolini MA, Sartori MG, Girão MJ. Randomized controlled trial comparing TVT-O and TVT-S for the treatment of stress urinary incontinence: 2-year results. Int Urogynecol J Pelvic Floor Dysfunct 2014;25(10):1343-1348

4 Schimpf MO, Rahn DD, Wheeler TL, et al; Society of Gynecologic Surgeons Systematic Review Group. Sling surgery for stress urinary incontinence in women: a systematic review and metaanalysis. Am J Obstet Gynecol 2014;211(01):71.e1-71.e27

5 Chantarasorn V, Shek KL, Dietz HP. Sonographic appearance of transobturator slings: implications for function and dysfunction. Int Urogynecol J Pelvic Floor Dysfunct 2011;22(04):493-498

6 Dietz HP. Ultrasound imaging of the pelvic floor. Part II: threedimensional or volume imaging. Ultrasound Obstet Gynecol 2004;23(06):615-625

7 Chene G, Cotte B, Tardieu AS, Savary D, Mansoor A. Clinical and ultrasonographic correlations following three surgical anti-incontinence procedures (TOT, TVT and TVT-O). Int Urogynecol J Pelvic Floor Dysfunct 2008;19(08):1125-1131

8 Ulmsten U, Henriksson L, Johnson P, Varhos G. An ambulatory surgical procedure under local anesthesia for treatment of female urinary incontinence. Int Urogynecol J Pelvic Floor Dysfunct 1996;7(02):81-85, discussion 85-86

9 de Leval J. Novel surgical technique for the treatment of female stress urinary incontinence: transobturator vaginal tape insideout. Eur Urol 2003;44(06):724-730

10 Bianchi-Ferraro AM, Jarmy-Di Bella ZI, Castro RdeA, Bortolini MA, Sartori MG, Girão MJ. Single-incision sling compared with transobturator sling for treating stress urinary incontinence: a randomized controlled trial. Int Urogynecol J Pelvic Floor Dysfunct 2013;24(09):1459-1465

11 Ethicon, a Johnson \& Johnson Company, makes allegedly dangerous transvaginal mesh and hernia mesh products [Internet]. 2012 [cited 2016 Jan 12]. Available from: http://www.yourlawyer.com/ topics/overview/johnson-johnson-ethicon-gynecare-transvaginal-mesh-complications-side-effects-lawsuits

12 Hahn I, Fall M. Objective quantification of stress urinary incontinence: a short, reproducible, provocative pad-test. Neurourol Urodyn 1991;10(05):475-481

13 Fonseca ESM, Camargo ALM, Castro RA, et al. Validation of a quality of life questionnaire (King's Health Questionnaire) in Brazilian women with urinary incontinence. Rev Bras Ginecol Obstet 2005;27(05):235-242

14 Dietz HP. Pelvic floor ultrasound in incontinence: what's in it for the surgeon? Int Urogynecol J Pelvic Floor Dysfunct 2011;22(09): 1085-1097

15 Tonni G, Lituania M. OmniView algorithm: a novel 3-dimensional sonographic technique in the study of the fetal hard and soft palates. J Ultrasound Med 2012;31(02):313-318

16 Agrest A. Categorical data analysis. New York: Wiley Interscience; 1990

17 Neter J, Kutner MH, Nachtsheim CJ, Wasserman W. Applied linear statistical models. 4th ed. Boston: Irwin; 1996

18 deTayrac R, Deffieux X, Droupy S, Chauveaud-Lambling A, Calvanèse-Benamour L, Fernandez $\mathrm{H}$. A prospective randomized trial comparing tension-free vaginal tape and transobturator suburethral tape for surgical treatment of stress urinary incontinence. Am J Obstet Gynecol 2004;190(03):602-608

19 Foulot H, Uzan I, Chopin N, Borghese B, Chapron C. Monarc transobturator sling system for the treatment of female urinary stress incontinence: results of a post-operative transvaginal ultrasonography. Int Urogynecol J Pelvic Floor Dysfunct 2007;18(08):857-861

20 Duckett J, Aggarwal I, Patil A, Vella M. Effect of tension-free vaginal tape position on the resolution of irritative bladder symptoms in women with mixed incontinence. Int Urogynecol J Pelvic Floor Dysfunct 2008;19(02):237-239

21 Dietz HP, Mouritsen L, Ellis G, Wilson PD. Does the tension-free vaginal tape stay where you put it? Am J Obstet Gynecol 2003;188 (04):950-953

22 Lin KL, Juan YS, LoTS, Liu CM, Tsai EM, Long CY. Three-dimensional ultrasonographic assessment of compression effect on urethra following tension-free vaginal tape and transobturator tape procedures. Ultrasound Obstet Gynecol 2012;39(04):452-457

23 Dietz HP, Mouritsen L, Ellis G, Wilson PD. How important is TVT location? Acta Obstet Gynecol Scand 2004;83(10):904-908

24 Kociszewski J, Rautenberg O, Kolben S, Eberhard J, Hilgers R, Viereck V. Tape functionality: position, change in shape, and outcome after TVT procedure-mid-term results. Int Urogynecol J Pelvic Floor Dysfunct 2010;21(07):795-800

25 Spelzini F, Cesana MC, Verri D, Polizzi S, Frigerio M, Milani R. Three-dimensional ultrasound assessment and middle term efficacy of a single-incision sling. Int Urogynecol J Pelvic Floor Dysfunct 2013;24(08):1391-1397 